\title{
FEATURES OF LOAN SECURITY FOR THE REPRODUCTION OF FIXED ASSETS FOR AGRICULTURAL PURPOSES
}

\author{
Yuliia Aleskerova' ${ }^{1}$, Lidiia Fedoryshyna ${ }^{2}$, Natalia Koval ${ }^{3}$
}

\begin{abstract}
The purpose of the article is to justify features of credit support for reproduction of basic agricultural products. It is shown that the modern financial system of Ukraine is in a state of prolonged decline, the output of which depends on the innovation activity of all subjects of the financial system, on the effective reproduction of fixed assets and the adequate financial and credit mechanism of its provision for agricultural enterprises. Methodology. There are several stages of reproduction of fixed assets of agricultural enterprises. At the first stage, there is a productive use of fixed assets. At this stage, they wear out and, accordingly, the amount of wear is calculated. It is the basis for the cancellation of the amount of depreciation deductions for costs after the completion of the production process. At the first stage of the turnover of fixed assets, the lost value of means of labour is lost. It is carried over to the cost of finished products. At the second stage, the transformation of the worn out of fixed assets, which were in a productive form, into cash, is taking place. On the third stage, in the process of production, there is an update of the consumption value of the fixed assets. This update is carried out by replacing the worn core production assets with new ones due to the accumulated depreciation of fixed assets. Results. Thus, it is established that the process of reproduction of fixed assets of agricultural enterprises is characterized by a number of features. The main ones are: a gradual write-off of cost to production costs; partial reproduction of the value in the finished product and its accumulation in cash; a long-time interval required for the renewal of fixed assets in a naturally real form; the need to attract significant one-time cash expenditures. Practical implications. Thus, the peculiarities of credit support for the reproduction of fixed assets of agricultural enterprises are: the objective necessity of its implementation due to the unprofitableness of the industry and the impossibility for a large part of agricultural enterprises, from their own sources, to provide a simple and extended reproduction of fixed assets; seasonal production; necessity of state support of the crediting process of reproduction of fixed assets. Value/originality. Thus, credit support for the reproduction of fixed assets of agricultural enterprises is the obligation of an agrarian enterprise to a credit institution, which must be paid out over a period of more than one year from the date of drawing up the balance sheet, as well as the prolongation of short-term loans used by the enterprise solely for the purpose of reproduction of fixed assets.
\end{abstract}

Key words: credit, reproduction, fixed assets, agricultural enterprises, seasonality, banking practice, leasing.

JEL Classification: F65, G21, P34, Q12

\section{Introduction}

At the present stage of the market relations, agricultural enterprises are faced with the difficulties of reproduction of production potential. They have to reduce their production, which reflects on the level of profits and consolidation in the society the idea of the futility of investing funds in this area of the economy.

Agricultural business requires significant support for the process of reproduction of resource potential. Among the most important factors of economic growth,

\footnotetext{
Corresponding author:

${ }^{1}$ Vinnytsia National Agrarian University, Ukraine.

E-mail: tuv@email.ua

${ }^{2}$ Vinnytsia National Agrarian University, Ukraine.

E-mail: fedorishina@i.ua

${ }^{3}$ Vinnytsia National Agrarian University, Ukraine.

E-mail: natkov@i.ua
}

the main place belongs to the state of resources of enterprises, in particular, fixed assets.

Most of the sources of their reproduction are important loan security. Objective necessity of application of a loan to reproduce the main means is due to specifics of the reproduction process in a sector that has a seasonal nature. At present, under low profitability levels of agricultural enterprises and investment attractiveness of the agrarian sector, credit support for the reproduction of fixed assets is a significant source of formation of the resource base of agricultural production. Problematic 
aspects of lending of agricultural enterprises is increased by the fact that the vast majority of them are characterized by low levels of liquidity, a significant increase in the depreciation period over norms and high levels of the depreciation of fixed assets and, in addition, the lack of necessary deficits of own funds to finance reproduction processes. This leads to a rapid increase in the significance of the disclosure of fundamental characteristics and theoretical elaboration of effective guidelines for improving credit support for the restoration of basic agricultural production enterprises.

In order to overcome such negative trends as one of the main directions, it is necessary to restore the material and technical base of agriculture. This is due to the fact that "the process of social production of material goods is objectively closely related to the functioning of two main factors - the labour force and means of production" (Aleskerova, 2008) and also that "the content of market transformations in the transformational economy allows us to assert that their basis is the change in the economic form of material factors of production, namely, their capitalization as a process of transforming production into real market goods" (Koval, 2011).

\section{Economic crisis effects on consumer behaviour}

The cost of fixed assets of one of the leading sectors of the national economic complex of Ukraine agriculture - at the beginning of 2006 was 47.13 billion $\mathrm{UAH}$, while in $2000-88.76$ billion UAH, and in 1996 - 121.33 billion UAH. That is, the cost of fixed assets for agricultural purpose is reduced annually. The main reason for this is the insignificant volumes of their updating. Depreciation of fixed assets exceeds their renewal by more than 10 times. In domestic agriculture, according to the majority of researchers, the possibilities of simple reproduction of material and technical base are lost; there is an intensive process of industrial deindustrialization, structural imbalance, and the shortage of certain types of resources, which affects the effectiveness of their use (Aleskerova, 2008).

At the same time, the reproduction of agricultural production is largely due to ensuring the effective use and renovation of production potential. The need to identify the trends, problems, and peculiarities of reproduction of fixed assets and their investment, as well as the development of recommendations for improving the investment security of the reproduction process in agriculture, determines the topicality of research relating to the loan security for the reproduction of basic agricultural products.

Such a study will make it possible to define clearly the structure of economic relations, which are formed in the process of loan security for the reproduction of fixed assets of agricultural enterprises: to reveal more fully the specifics of the relationship of elements and forms of loan security; to identify their fundamental features as sources of innovation activity, affecting the state of the field of agriculture.

In this connection, in market conditions of management, a fundamentally new approach to the organization of loan security is required to restore the basic assets of the agrarian sector of the economy, its improvement through active measures at the level of agricultural enterprises themselves, as well as state administration, the creation of new financial and credit structures. All this proves once again the necessity to study the financial support of the reproductive process in agriculture and to justify new approaches to their solution, in particular, to develop an effective and efficient mechanism of loan security.

Especially acute the problem of reproduction of fixed assets, as a component of innovation, appears on the transitional stages of economic development and during the periods of economic crises. The modern domestic economy is in a state of prolonged decline, getting out of which depends on the innovation activity of all subjects of the economic system, on the effective reproduction of fixed assets and the adequate financial and credit mechanism for its providing.

The development of agriculture is constrained by a number of reasons. The main one is the lack of resources to finance the development. The increase in the size of production assets is possible only due to additional investments of financial and material resources, aimed at supporting and expanding the production potential of agriculture. Since the possibilities of reproduction of fixed assets at the expense of profits and depreciation fund are rather limited, agricultural enterprises require the attraction of credit resources.

The composition of fixed assets of agricultural enterprises is quite different and can be classified according to various features. Means and objects of labour in commodity production acquire the value through the market. They transfer it during the production process to the produced product. By the way of participation in the production and transfer of its value to the newly created product, the means of labour are divided into basic and reversible.

So, the essence of the category of "fixed assets" is rather ambiguous. Without going into the discussion, we note that the categories of "fixed funds", "fixed assets", and "fixed capital" provide the agricultural enterprises with the means and objects of labour, and exactly their structure and proportions make it possible to improve the mechanism of reproduction of fixed assets.

The main feature of agricultural enterprises is their organic composition, species characteristics, functional purpose. It is important to participate in technological processes and to maintain certain proportionality in their composition. In particular, this proportionality refers to the ratio between power machines: tractors, combines, cars, and the amount of land cultivated, tractors and agricultural machines, the area of industrial premises and livestock or facilities, etc. 
The main productive assets are reproduced through capital investments, the sources of which are the own funds (deductions from profits and depreciation deductions), as well as involved ones.

Features of reproduction of various parts of the means of production determine the difference in their loan security. In particular, reversible assets should be reproduced in one production cycle, and the main ones - during their complete wear and tear. At the same time, the wear period depends on the composition of the means of production and the accepted form of the accounting for their wear.

The reproduction of basic productive assets is a process of the continuous renewal. By the volume, the following forms of reproduction are distinguished: simple, extended, and narrowed. A simple reproduction of fixed assets is carried out in the same amount, that is, when the replacement of certain worn parts of fixed assets occurs, or the replacement of old equipment with a similar one, that is, when the previous production capacity is constantly restored.

The extended reproduction involves the quantitative and qualitative increase of the existing fixed assets or the purchase of new ones that provide a higher level of equipment productivity. With reduced reproduction, there is a decrease in the amount of used means of production in each successive cycle.

The process of reproduction of fixed assets has a number of distinctive features, in particular:

1) they gradually transfer their value to the manufactured products;

2 ) in the process of their reproduction, the movement of their consumer value and cost takes place simultaneously;

3) accrual of amortization deductions is carried out by accumulation in the monetary form of the transferred cost of the main production facilities for finished products;

4) fixed assets are renewed in kind for a long time, which makes it possible to manoeuvre the funds of the depreciation fund.

In the process of economic activity, the circulation of fixed assets passes three stages. At the first stage, the productive use of fixed assets takes place. It is the basis for the cancellation of the amount of depreciation deductions for the cost after the end of the production process. At the first stage of the circulation of fixed assets, the exchange cost of labour is lost. It is transferred to the cost of finished products.

At the second stage, the transformation of the worn part of fixed assets, which were in a productive form into cash, takes place.

At the third stage in the process of production, there is a renewal of the consumer value of the part of fixed assets. This renewal is carried out by replacing worn core production assets with new ones due to the accumulated wear of fixed assets Todosiychuk Yu. V. (2007). The features of the reproduction of the main assets of the branch under study are that agriculture is connected with many other industries - forming an agro-industrial complex, the main task of it is to secure the country's food supply and agricultural raw materials.

Unlike other sectors of the national economy, the production there is carried out in large territories with different relief, climate, and soils. In agriculture, many production processes are seasonal in nature, connected with natural conditions of plant growth and animal development.

\section{Differences in consumer spending behaviour among age groups}

The land is the basis of farming - a non-renewable unique natural resource. Thus, it has been established that the process of reproduction of fixed assets of agricultural enterprises is characterized by a number of features. The main ones are:

$>$ Gradual writing-off the value on production costs; $>$ partial reproduction of the value in the finished product and its accumulation in cash;

$>$ a long time interval required for the renewal of fixed assets in a naturally real form;

$>$ the need to attract significant one-time cash expenses.

V. S. Shebanin notes that from 1990 to 2000, the investments in agriculture decreased by 24 times, while in the industry - only by 3.4 times. The level of investment in 2006 was only $60 \%$ of the 1990 level. Consequently, "even for the account of all sources of financing, now the investment process does not provide not only extended but even a simple reproduction of fixed assets, consumed in the process of production activity" (Aleskerova, 2008).

The ensuring of agricultural production by fixed assets only by $60 \%$ led to gross violations and untimely implementation of certain technological operations. The losses of agriculture, associated with lack and low technical condition of machines, make up more than $30 \%$ for the lack of the harvest, about $15 \%$ for overfill fuel. The specific weight of unprofitable farms in the agrarian sector reached $85 \%$ of their total quantity, while the total debt of agricultural enterprises approached 15.2 billion UAH (Aleskerova, 2008).

The difference in the composition of fixed assets and the target nature of lending require an object-oriented approach to the formation of the sources involved in the funding of these activities. So, the objects of lending are specific elements of fixed assets or their aggregates, such as buildings, machinery, and equipment serving a separate production process.

Such loans can be provided to agricultural enterprises for capital investments related to the reconstruction of the enterprise, its technical re-equipment, the introduction of new technology, the improvement of production technology. 


\section{Survey methodology}

On the other hand, different parts of fixed assets have a different period of turnover. Taking into account that the term of their use exceeds a year, medium and long-term credits are the main types of loan security for their renewal. At the same time, as the analysis of the structure of fixed assets shows, most of them have a term of use for more than five years. So, the main type of loan security for their reproduction is long-term loans.

Banks issue loans for capital investments, if the calculations of economic efficiency show that for one or another period after the object introduction into operation, the company will have additional financial resources in the form of profit that can be used to repay the loan and interest for its use.

Unfortunately, the inflation rate in Ukraine in recent years and the practice of forming the value of loans by creditors virtually nullified the issue of long-term loans to enterprises for the reproduction of fixed assets. By the level of bank rate that is demanded by the banks, it is often impossible to achieve the payback of costs on the capital investment.

For a comparison, in the period of 1970-1990 in the total volume of financing, from 17 to $40 \%$ of the credit resources, directed into agriculture, was allocated for the purchase of technology. At the same time, "the structure of long-term loans in the total volume of agricultural production was 70-73\%". Characteristic was the gradual reduction of the share of capital investment in construction from $26 \%$ in $1976-1980$ to $7 \%$ in 1986-1990 and its increase in the purchase of tractors, vehicles, agricultural machinery, implements and equipment, the level of which for 1986-1990 increased by $46 \%$, for $1981-1985$ by $76-80 \%$.

At the present stage of the relationship in the mechanism of loan security, it is about the establishment of low-interest rates on long-term loans, not higher than $10 \%$. It is advisable to start the repayment of such loans for the third or fourth year of their use.

Agro-industrial enterprises in Ukraine have the right to receive loans in foreign banks (in foreign currency). Such a company's right is obtained by getting from the National Bank of Ukraine special registration certificates for obtaining a loan from a foreign bank. The Ukrainian company-borrower must receive such a registration certificate after signing a loan agreement with a foreign bank, but before the actual receipt of credit funds.

Thus, in the agrarian sphere of transition, a special credit system should be formed, for the development of which infrastructure special methods of state regulation should be applied. The latter should include the provision of favourable economic conditions by the state, legal support, the promotion of the establishment and development of market institutions and the direct participation in some of them (Koval, 2011).
Financial leasing is a complex of relations providing technical re-equipment of enterprises and accelerating scientific and technological progress by selling means of production with deferred payment and provision. Unlike a commercial loan, a financial leasing operation includes the provision of other services to the borrower (maintenance, etc.). The subjects of credit relations here are the lessor as a creditor and the lessee as a borrower (Koval, 2011).

The object of the leasing may be any real estate that can be attributed to fixed assets, which is not prohibited for free circulation in the market and for which there are no restrictions on the transfer in the leasing. Leasing objects include: machinery and equipment, means of computer facilities, vehicles, industrial buildings and structures, other fixed assets.

Financial provision of leasing operations is more reliable than ordinary lending since the allocated funds are used to purchase certain property that guarantees repayment of the debt. However, in this situation, there is a risk associated with ownership. That's why some leasing companies require a pledge or a bank guarantee.

The advantage of leasing in the field of the agroindustrial complex is that it excludes other forms of state regulation, for example, tax and credit privileges, and expands the access to expensive cars, provides services to the maintaining of the own car park, especially seasonal use, and the support by brand service.

The negative side of leasing is that much equipment received under leasing agreements is of poor quality and its technical condition does not meet the needs, and also the high cost of leasing operations. But these disadvantages are eliminated by the opportunity to attract additional financial resources to reproduce fixed assets when bank loans are not available.

\section{Findings}

Besides the considered peculiarities of reproduction of fixed assets at the expense of different types of loan security, the terms for which the loan is issued are important. In particular, according to the majority of researchers, the classification of the loan security for the reproduction of fixed assets is made depending on their term:

$>$ short-term loans up to 1 year;

$>$ prolonged short-term loans;

$>$ long-term loans over 12 months;

$>$ long-term loans up to 36 months;

$>$ long-term loans over 36 months.

Thus, the peculiarities of loan security for the reproduction of fixed assets of agricultural enterprises are:

1. The objective necessity of its realization due to the unprofitableness of industry and the impossibility for a large part of agricultural enterprises, to provide a simple and extended reproduction of fixed assets from their own sources. 
2. Seasonal production of agricultural enterprises and various force majeure circumstances require a significant withdrawal of working capital from turnover, which does not contribute to the accumulation of funds, even at the level of depreciation deductions for the reproduction process.

3. The need for the state support of the crediting process of reproduction of fixed assets as, at present, there is no real source of collateral for commercial loans because the agricultural land is not a commodity, therefore, it cannot be a pledge, when granting a loan to an agricultural enterprise for the reproduction of fixed assets. In addition, the high inflation rate does not make it possible to pay off in due time for the provided loan.

4. Difficulties in obtaining a lease loan, as most banks operate indirectly through leasing for agricultural enterprises.

Based on the peculiarities of reproduction of fixed assets and considered above scheme of classification of loan security for the participants of the credit process, it can be concluded that for the reproduction of fixed assets, it is possible to use all the forms, types, and varieties of loans. Herewith, depending on the purpose, not only medium and long-term loans, which are determined by the term of the use of fixed assets but also short-term ones can be used, if it is connected with the introduction of new technologies based on new techniques.
Effective use of new equipment in the formation of new production, as well as in the renovation and reconstruction of existing production requires some current costs. Such loans are necessary in order to return long and mediumterm loans in a timely manner and in full.

\section{Conclusions}

The conducted research allows to formulate the following definition that loan security for the reproduction of fixed assets of agricultural enterprises is an obligation of an agrarian enterprise to a credit institution, which must be repaid within a period exceeding one year from the date of drawing up the balance sheet, as well as the extension of short-term loans used by the enterprise exclusively for the purpose of reproduction of fixed assets.

Thus, the features of loan security for the reproduction of fixed assets, considered by us, are to take into account the industry specifics and the structure of fixed assets and determining the types of loan, that can be involved by agricultural enterprises for the formation of resources.

The conducted research indicates that the relations of crediting for the reproduction of fixed assets are at the initial stage of their development. This is confirmed by the non-proliferation or insufficient use in banking practice of the types of loans, necessary for agricultural commodity producers, which are common in other sectors of the economy.

\section{References:}

Aleskerova, Yu., Mulyk, T., Fedoryshyna, L. (2018). Improving credit protection analysis methods Reports of main agricultural enterprises. Baltic Journal of Economic Studies, 4(2), 1-7.

Aleskerova, Yu., Fedoryshyna, L. (2018). Analysis of investment activities of enterprises of Ukraine. Economic system development trends: the experience of countries of Eastern Europe and prospects of Ukraine.

Aleskerova, Yu. V. (2008). Analiz stanu ta efektivnosti kreditnogo zabezpechennya vidtvorennya osnovnikh zasobiv silskogospodarskikh pidpriemstv [Analysis of the status and effectiveness of credit support for reproduction of fixed assets of agricultural enterprises]. Oblik i finansi APK, 3, 125-129.

Koval, N. I. (2011). Oblik finansovoi diyalnosti agrarnikh pidpriemstv na vimogi finansovogo menedzhmentu [Accounting of financial activity of agrarian enterprises for the requirements of financial management]. All-Ukrainian Scientific and Production Magazine «Innovative Economy». Ternopil Institute of Agricultural Production, 7(26), 26, 132-136.

Todosiychuk, Yu. V. (2007). Vidi ta formi kreditiv u zabezpechenni vidtvorennya osnovnikh zasobiv [Types and forms of loans to ensure the reproduction of fixed assets]. Ekonomika APK, 12, 98-101. 